\title{
Earnings Quality: A Missing Link between Corporate Governance and Firm Value
}

\begin{abstract}
Khalid Latif ${ }^{1}$, Arshad Ali Bhatti², Abdul Raheman ${ }^{3}$
Abstract

The existing literature concerning governance-value relationship is inconclusive as it assumes that the association is direct. A theoretical argument suggests that the effective corporate governance reduces the information asymmetry through better financial reporting quality. This serves as a tool to reduce this information risk. Following the argument, our study is an attempt to investigate the mediating role of earnings quality, a measure of financial reporting quality, in governance-value association. For estimation, we use a panel data of 214 non-financial listed firms in Pakistan for the period 2003-2014 and employ one-way random effect estimator for the SUR system, as suggested by Biørn (2004). Our findings show that the corporate governance effectively improves the earnings quality and value of the firm, which approves the monitoring role. Moreover, earnings quality contributes positively in maximizing the value of the firm and the results demonstrate that better earnings quality partially mediates the governance-value association. It is concluded that corporate governance not only improves the value of the firm directly, but also indirectly through the channel of earnings quality.
\end{abstract}

Keywords: Earnings quality, overall corporate governance, value of the firm, indirect effect

\section{Introduction}

In this age of information, individuals have quick access to required information through the internet, social media and print media etc., living in any part of the world. However, such information does not guarantee the same quality and transparency. If this is a fact of the present day life, then it is true for capital markets as well. Capital markets act as intermediaries between parties, having surplus funds and parties which

1 PhD Scholar, International Islamic University, Islamabad, Pakistan. Email: khalidlatif382@gmail. com

2 Assistant Professor, International Islamic University, Islamabad, Pakistan. Email: arshad_bhatti@iiu. edu.pk

3 Associate Professor, International Islamic University, Islamabad, Pakistan. Email: abdul.raheman@ iiu.edu.pk

\begin{tabular}{lll} 
ARTICLE HISTORY & \\
5 Feb, 2017 Submission Received & 10 Mar, 2017 & First Review \\
\hline $12 \mathrm{Mar}, 2017$ Second Review & $30 \mathrm{Mar}, 2017$ & Revised Version of Both Reviews \\
\hline $1 \mathrm{Apr}, 2017$ & &
\end{tabular}

1 Apr, 2017 Accepted 
need these funds. Information is a significant component of capital markets (Nita, 2007). The internal accountability of a firm is presented to the stakeholders and capital market participants in the form of financial statements. The basic objective of financial reporting is to disseminate the financial information to stakeholders for economic decision making (Board, 2010).

However, the reported earnings are a key source of financial statements for investors, market analysts and managers. It is also a major determinant of stock price (Shan, 2015). Prospective investors have faith in earnings as compared to other factors. However, market analysts' stock recommendations, reports, target pricing and earning forecasting are important for stock price foundation (Salerno, 2013). Managers of the firm have to disseminate useful information to attract capital investments and they use these funds in projects which increase the stockholders' wealth. But firm managers have several incentives to "meet the numbers" and also certain discretions to influence the earnings figure. This opportunistic behavior of managers towards reported earnings affects the stakeholder relationships, corporate reputation and hence the value of the firm (Rodriguez-Ariza, Martínez-Ferrero, \& Bermejo-Sánchez, 2016).

During the valuable decision making process regarding a firm, the key factors of accounting information are reliability, usefulness and relevance. The existence of these factors influences the user of accounting information to confirm or correct the past decisions or to make predictions (DeFond, 2010). The accounting information is considered valuable and reliable if it is presented without any bias. Furthermore, poor earnings quality delivers misleading information to the stakeholders (Ismail \& Elbolok, 2011). However, in emerging economies, high levels of earning management and fabrication are experienced, as compared to developed economies. Hence, investors lose confidence in reported earnings (Leuz, Nanda, \& Wysocki, 2003; Pincus, Rajgopal, \& Venkatachalam, 2007).

To mitigate the effect of discretionary accounting, corporate governance system can play an effective role. Claessens and Yurtoglu (2013) assert that in emerging economies, corporate governance faces a number of challenges, for example concentrated ownership structure, low level of institutional ownership and non-existing or underdeveloped markets for debt and equity. Gaio and Raposo (2014) document that the country effect is also important for explaining the impact of corporate governance mechanisms on earnings quality. For developed economies, this association is stronger than that of those developing.

Habib and Jiang (2015), identify that financial reporting quality should contribute to the value of firm through reduction of information symmetry. They also argue that as a direct output of corporate governance mechanism, financial reporting processes 
have the ability to provide useful information for the reduction of information risk and hence a decrease in cost of the capital. This study therefore explores the governance-value relationship from a new perspective, that is, the role of earnings quality as a mediating variable in the determination of governance-value relationship, which is the main objective of the study.

Literature is silent about the indirect effect of financial reporting quality in the governance-value relationship. Governance-value relationships without this aspect provide only a partial picture. It is therefore a contribution of our study as the existing governance-value studies are undermined by this important missing link. Secondly, in contrast to considering the various corporate governance elements individually as other studies in Pakistani context, corporate governance index is being constructed using Principal Component Analysis (hereafter PCA), a statistical technique. Prior corporate governance indices are constructed by assigning weights based on researchers' own subjective judgments. The third dimension is that there is no evidence of studies in Pakistan regarding earnings quality measurement and reaction of firm value to earnings quality. Another dimension is that the study uses various measures of earnings quality for the detection of reliability and relevancy of financial statements. Lastly, in this study, recent data is being used in the context of Pakistan that enables to address the issue with an experimental setting with larger sample period and quantity of firms. 214 sample firms are being selected over the period 2002 to 2014. Other studies in the Pakistani context have used the sample of 120 or less firms and for the period of up to five years only.

Our results show that corporate governance has positive effect on the value of the firm and it serves as a monitoring role in improving the reliability and relevancy of financial reporting. Both dimensions are measured through five attributes. As regard to mediating effect of these attributes of earnings quality in the governance-value association, the results indicate that reliability and relevancy of financial reporting are significant contributing factors in the association between corporate governance and value of the firm. Testing the mediating role of earnings quality has been found distinct in the context of Pakistan.

\section{Literature Review}

\subsection{Earnings quality as a measure of financial reporting quality}

The statement of Financial Accounting Concept No. 1 of FASB ${ }^{4}$ explains the objectives of financial reporting in the words "through financial reporting, information is disseminated to various stakeholders for their decision making

4 Financial Accounting Standard Board 
process regarding rational investment, financing and other decisions". This information should be comprehensive and understandable to those who have reasonable understanding of business activities and are ready to study the information with due diligence (Tasios \& Bekiaris, 2012).

However, the financial reporting quality is not an indicator that could easily be quantifiable because it could not be directly observed. In literature, five ways/proxies are adopted to measure the financial reporting quality: (1) Standard and poor's transparency index; (2) Auditor's litigation; (3) analyst reporting (4) auditor's opinion and (5) earnings quality. In a study, based on U.S.A. data, to measure the quality of financial reporting, Frost, Gordon, and Pownall (2005) use the S\&P transparency and disclosure index score. This score is calculated as the percentage of disclosure items from a list of 35 items in annual reports. For example if 30 of the 35 items appear, then respective firm has "decile rank" of 9 ( $85 \%$ rounded up to 90 , and then divided by 10 ). As higher audit quality improves the financial reporting credibility by deterring opportunistic behavior of managers and decreasing the litigation risk for fake and fraudulent financial reporting, auditor litigation may be a proxy to measure the quality of financial reporting (Skinner \& Srinivasan, 2012).

The other proxy to measure the quality of financial reporting is the analyst's rating of disclosure. Perotti and Wagenhofer (2014) observe and report that the several items in financial statements like big lease obligations, high goodwill, debt level and growth in revenue from non-operating items serve as inverse measures of financial reporting quality.

Pucheta Martínez and García Meca (2014) consider the auditor's opinion as a proxy to measure the quality of financial reporting. In this study, the auditor's report is considered to be informative for stock returns. In case of a qualified report, dummy variable 1 , otherwise 0 is taken. Another proxy to measure the quality of financial reporting is the earnings quality, which is considered as a broader measure of financial statement quality (Gaio \& Raposo, 2014; Kim, Lee, \& Chung, 2015). According to SFAC 5 No.2, understandability, relevance, reliability and comparability are the qualitative characteristics that ensure the usefulness of financial accounting information for users. Yet, individual users have different perceptions of the usefulness of the information and their perception of quality can vary, so the assessment of usefulness cannot be directly observed (Braam \& Beest, 2013).

Dechow, Ge, and Schrand (2010) rank the earnings quality into three categories: (1) the reported earnings should reflect the current performance, (2) the reported earnings should be a good indicator of future performance, and (3) it should annu-

5 Statement of Financial Accounting Concepts 
itize the intrinsic value of the firm. In this study, the quality of financial reporting is measured through the quantitative measures which focus on reliability and relevancy of financial reporting ( Gray, Turner, Coram, \& Mock, 2011; Palea, 2013). On the basis of relevancy and reliability, financial reporting is considered useful and valuable to stakeholders in their decision making process. For reliability dimension, persistence, predictability, and value relevance a taken into account. For relevancy dimension, accrual quality and smoothness are taken in to account (Dechow, Ge, \& Schrand, 2010; Gaio \& Raposo, 2014). Lyimo (2014) argues that there is no complete consistency among various techniques of measuring earnings quality and therefore investors, analysts and market participants should not be dependent upon only one measure of earnings quality.

\subsection{The nature of relationship between corporate governance and earnings quality attributes}

Because of separation of ownership and control, the managers have superior information and know more than the shareholders. This results in an asymmetric information issue. The underlying assumption of the Positive Accounting Theory is that the managers act for their private interests and are involved in opportunistic activities (Watts \& Zimmerman, 1986). A better corporate governance mechanism is likely to curbs the managerial opportunist behavior, minimizes the risks related to financial reporting quality (Akileng, 2014). Country effect is also important in developing the relationship between corporate governance and earnings quality and this relationship is strong in developed economies as compared to those developing, with weaker investor protection (Gaio \& Raposo, 2014). Jiang, Lee, and Anandarajan (2008), studies the relationship between corporate governance and earnings quality taking a comprehensive measure of corporate governance and absolute discretionary accruals as the proxy for earnings quality on the 4,311 firm-year observations over the period 2002-2004. Using multivariate analysis, they show that the corporate governance score is negatively associated with discretionary accruals and positively associated with earnings quality.

Aldamen and Duncan (2016), examine the likelihood of overall corporate governance in improving the earnings quality among 340 firms listed on Australian Securities Exchange for the period 2006 to 2010. They construct a corporate governance index using PCA and accrual quality as a measure of earnings quality. They find that good corporate governance has a significant positive relationship with earnings quality. From a theoretical perspective, firms with good corporate governance are expected to enhance financial reporting quality. So, for the research question "what is the relationship between overall corporate governance and earnings quality attributes", 
the hypothesis is as below:

H1: Good corporate governance increases the level of earnings quality.

\subsection{Corporate governance and value of the firm-mediating role of earnings quality}

Company is a separate legal entity with the set of agreements (formal and informal) which allow principals to appoint agents to execute the designated services on their behalf (Jensen \& Meckling, 1979). They also describe the agency problem as "if both principal and the agent are utility maximizers, then there is a good reason that both parties' interests are misaligned". The stewardship theory is also relevant to the principal-agent relationship. In contrast to the agency theory, it asserts that both the principal and agent have interest in maximization of long term company stewardship and are therefore aligned (Lambright, 2009). The corporate governance concept is based on the agency theory and stakeholder's theory, which ensures investors return on their investments.

Klapper and Love (2004) examine the firm level data of 14 emerging stock markets; Chile, Hong Kong, Brazil, Indonesia, Pakistan, Taiwan, India, Philippines, Malaysia, Singapore, South Africa, South Korea, Thailand and Turkey, with Tobin-Q and ROA. They find a significant positive link among the corporate governance mechanism and the firm's performance. They also find that there is an extensive discrepancy in the firm level corporate governance among various economies, and that corporate governance level is lower in economies having weaker legal system.

Ammann, Oesch, and Schmid (2011) studies the nature of the governance-value relationship by taking 22 developed countries for the years 2003 to 2007. They develop three various corporate governance indices and find a significant positive association between corporate governance and firm value. However, some studies question the positive governance-value relationship and claim that this relationship is not so strong (Akbar, Poletti-Hughes, El-Faitouri, \& Shah, 2016; Shah and Butt, 2009).

Bushman and Smith (2001) posit that the financial accounting information can affect the cost of the capital through three channels: (1) by delivering the valuable information to stakeholders for better project identification, which reduces the estimation risk and hence the cost of the capital, (2) by reducing in information asymmetry between stakeholders, which decreases the liquidity risk of investors and the cost of the capital (adverse selection) and (3) by providing valuable information that would be used in corporate control mechanism, which reduces the misappropriation risk and hence the cost of the capital (governance channel). 
Recently, Habib, and Jiang (2015) suggest that a higher financial reporting quality contributes towards firm's value in three ways: (1) support to select or reject the good or bad projects, (2) reduction of misappropriations of the managers and (3) reduction of information asymmetry among managers and investors. In their survey based study, they theorize that studies regarding the association between corporate governance and value of the firm are conducted without the crucial role of financial reporting quality as it is an important output of effective corporate governance mechanism. The past studies are limited to investigating the impact of corporate governance either on financial reporting quality or on the value of the firm separately, without studying the effect of corporate governance on the value of firm through financial reporting quality. In contrast to the prior studies of governance value association, it is hypothesized that corporate governance does not directly affect the value of firm. Instead, the financial reporting quality serves as a intervening variable through which corporate governance affects the value of the firm (Kang \& Kim, 2011).

The literature review and argument presented by (Habib \& Jiang, 2015), motivate us to investigate whether earnings quality strengthens the governance-value association or not. Thus, our study investigates the indirect link among corporate governace and value of firm mediated by earnings quality. Accordingly, for research question "does earnings quality mediate the association among overall corporate governance and the firm's value", the hypothesis is as under:

H2: Earnings quality mediates the relationship between corporate governance and value of the firm.

\section{Methodology}

\subsection{Sample selection}

In this study, sample firms listed on the Karachi Stock Exchange for the period 2003-2014 have been used. Financial institutions have distinct regulatory environments, capital structure and accounting methods (Firth, Fung, \& Rui, 2007). Therefore, 130 financial firms are excluded from the sample. The sample size has also been decreased by 213 firms, because of the delisting or non-availability of online annual reports during the sample period. After elimination, the remaining sample consisting of 214 firms has been obtained for the estimation. Annual reports of non-financial firms and online sources have been used to obtain relevant data. Annual share price 
Table: 1 Final Sample of the Study

\begin{tabular}{|c|c|}
\hline Sample Selection from 2003 to 2014 & 557 \\
\hline $\begin{array}{c}\text { Total number of firms listed on Karachi Stock Exchange } \\
\text { Less: Firms Excluded due to insufficiency of data or delisted during the sample } \\
\text { period }\end{array}$ & (213) \\
\hline $\begin{array}{c}\text { ing firms and Modarabas. } \\
\text { Final Sample of the study }\end{array}$ & 214 \\
\hline
\end{tabular}

data is being extracted from the Karachi Stock Exchange and related sources. Table 1 describes the selection procedure of the final sample.

\subsection{Measurement of Overall Corporate Governance (OCG)}

Extensive literature, which captures the impact of corporate governance and value of firm and other financial aspects is available, but there is no consensus on the measurement of corporate governance (Al-Malkawi, Pillai, \& Bhatti, 2014; Shahwan, 2015). In the recent years, the corporate governance index approach is common for the assessment of corporate governance practices. However, most of these studies are in the context of developed economies ( Bhandari, Lamba, \& Seth, 2013; Gompers, Ishii, \& Metrick, 2003; Varshney, Kaul, \& Vasal, 2012). In Pakistan, Ali Shah and Butt (2009) conducted a first study using the corporate governance index. They allocate weights to ownership and board characteristics. However, the weight assigned to various corporate governance components to develop an index is a critical issue and based on subjective judgments (Javed, Iqbal, \& Hasan, 2006). Therefore, the construction of the corporate governance index is problematic and there is a lack of agreed and dominating approach.

In above mentioned studies, corporate governance indices are developed on the basis of multiple dimensions of corporate governance. In this study, nine important dimensions have been identified for the construction of corporate governance score (Ali Shah \& Butt 2009; Madhani, 2014). Then Principal Component Analysis is used to develop the overall corporate governance score.

\subsection{Measurement of earnings quality (EQ) attributes}

Since earnings quality cannot be observed directly, literature provides a range of proxies used to measure it. These measures are given as follows:

\subsubsection{Persistence (PRS)}

Persistence refers to current earnings that reoccur in future and sustainability of 
reported earnings of a firm (Penman \& Zhang, 2002). Francis, LaFond, Olsson, and Schipper (2004) estimate the slope coefficient, , from the following regression model:

$$
\operatorname{NIBE}_{j, t} / \text { TASSETS }_{j, t-1}=\beta_{0}+\beta_{1} \text { NIBE }_{j, t-1} / \text { TASSETS }_{j, t-1}+\varepsilon_{j, t}
$$

where, NIBEj,t and NIBE $_{j, t-1}$ are net income before extra-ordinary items in time $\mathrm{t}$ and $\mathrm{t}-1$ for $\mathrm{j}$ firm, TASSETS $\mathrm{j}_{\mathrm{j}, \mathrm{-1}}$ are the total assets of $\mathrm{j}$ firm in year $\mathrm{t}-1$ and $\varepsilon_{\mathrm{j}, \mathrm{t}}$ is the error term.

For each firm, equation (1) is estimated over rolling five years windows and $\beta_{1}$ is obtained from year 1999 to 2014 . Higher $\beta_{1}$ shows a higher level of earnings quality.

\subsubsection{Predictability (PRED)}

Earnings prediction is an important feature of current reports (Penman \& Zhang, 2002). Larcker, Richardson, and Tuna (2007) use the estimated error term derived from earnings persistence regression by taking its square root as:

$$
\operatorname{PRED}_{j, t}=\sqrt{ } \sigma^{2}\left(\varepsilon_{j, t}\right)
$$

Here, larger value ofPRED ${ }_{\mathrm{j}, \mathrm{t}}$ is an indicator of better quality of earnings.

\subsubsection{Value relevance $(V R)$}

Ohlson (1995) comes up with a price model to examine the value relevance of accounting information as:

$$
\operatorname{SRET}_{j, t}=\beta_{0}+\beta_{1} \frac{N I B E_{j, t}}{M V E_{j, t-1}}+\beta_{2} \frac{\Delta N I B E_{j, t}}{M V E_{j, t-1}}+\varepsilon_{j, t}
$$

where, $\mathrm{MVE}_{\mathrm{j}, \mathrm{t}-1}$ is the market value of equity at the beginning of the year in time $t$ for $\mathrm{j}$ firm. For each firm, equation (3) is estimated over rolling five years windows. $\mathrm{R}^{2}$ measures how much change in dependent variable is explained by independent variable and higher value of $\mathrm{R}^{2}$ indicates higher value relevancy of accounting information.

\subsubsection{Accrual quality (AQU)}

Accrual quality is considered to be the degree of stability in the relationship between cash flows and accruals. The gap between earnings and cash is due to accruals. Dechow et al. (2010), develop a measure of accrual quality as under:

$$
\frac{\Delta \text { WCAP }_{j, t}}{\text { TASSETS }_{j, t-1}}=\beta_{0}+\beta_{1} \frac{\text { CFO }_{j, t-1}}{\text { TASSETS }_{j, t-1}}+\beta_{2} \frac{\text { CFO }_{j, t}}{\text { TASSETS }_{j, t-1}}+\beta_{3} \frac{\text { CFO }_{j, t+1}}{\text { TASSETS }_{j, t-1}}+\varepsilon_{j, t}
$$

$\triangle \mathrm{WCAP}_{\mathrm{j}, \mathrm{t}}$ is the difference between change in current assets and change in current liabilities in time $t$ for $j$ firm. $\mathrm{CFO}_{j, t}, \mathrm{CFO}_{j, t-1}$ and $\mathrm{CFO}_{j, t+1}$ represents the firm $\mathrm{j}$ 's cash flow from operations in time $t, t-1$ and $t+1$. 
For each firm, equation (4) is estimated over rolling five years windows to calculate the standard deviation of the residuals. Higher standard deviation of the residuals indicates low accrual quality.

\subsubsection{Smoothness (SM)}

Smoothening of earnings is the lesser volatility in the reported earnings over the time. Bowen, Rajgopal, and Venkatachalam (2008) divide the standard deviation of earnings and standard deviation of operating cash flows to calculate the degree of smoothness. However, Francis et al. (2004) use the same ratio by scaling both variables by lagged assets as:

$$
S M_{i, t}=\sigma\left(\frac{\operatorname{NIBE}_{j, t}}{\operatorname{TASSETS}_{j, t-1}}\right) / \sigma\left(\frac{\text { CFO }_{j, t}}{\text { TASSETS }_{j, t-1}}\right)
$$

Standard deviation is calculated over five years rolling windows. Large values of "SM" indicated less smoothness, which is a representation of higher earnings quality.

\subsection{Dependent variable-firm's value}

Both market (Tobin's $\mathrm{Q}$ ) and accounting performance (ROA) measures are used in this study. Tobin's $Q$ serves as a proxy for company performance in a financial market. A high $\mathrm{Q}$ value indicates the market's perception that the company performance is good (Weir, Laing, \& McKnight, 2002). Tobin's Q ratio is defined as market capitalization plus total debt divided by total assets.

$$
\text { Tobin's- } \mathrm{Q}=\frac{(\text { Equity market value }+ \text { Liabilities book value })}{(\text { Equity book value }+ \text { liabilities book vlue })}
$$

$\mathrm{ROA}$ is the accounting based measures of value of firm followed by (Mahoney $\&$ Roberts, 2007).

$$
R O A=\frac{E B I T}{\text { Total Assets }}
$$

\subsection{Control variables}

In this study, firm size, leverage, capital intensity and growth prospects are included to control for possible influences on earnings quality and value of the firm. As the size of the firms increases, the agency cost is expected to increase and allow for greater managerial discretions (Jensen \& Meckling, 1979; Watts \& Zimmerman, 1986). To control size effects (FS), the natural logarithm for the book value of total assets is included as a proxy for the size of the firm. Jiang et al. (2008), suggest that leverage changes may have different impacts on value and earnings quality. Dimitropoulos and Asteriou (2010) calculate leverage (LVG) as a total long term debt 
divided by total assets. Following Francis et al. (2004), proxy for capital intensity is the ratio of net book value of property, plant and equipment to total assets. Growth firms are expected to increase firm value and earnings quality but can be regarded as risky firms which inflate their earnings (Krishnan \& Parsons, 2008). To control these effects on earnings quality, growth $(\mathrm{GW})$ prospects are included and measured as the firm's market to book ratio of equity, calculated as market value of equity divided by book value of equity.

\subsection{Mediation analysis}

In mediation analysis, we examine the process through which our independent variable (overall corporate governance) exercises the impact on dependent variable (value of the firm) through a mediating variable (earnings quality). Mediation analysis goes beyond the description of impact of independent variable upon dependent variable, rather to explain how that relationship exists (Hayes \& Preacher, 2014).

Figure 3 shows the casual association among overall corporate governance, earnings quality attributes and value of the firm. We decompose the effects of overall corporate governance $(\mathrm{OCG})$ on value of the firm $(\mathrm{V})$ into direct and indirect effects. The direct effect of OCG on V is shown by "c", whereas the indirect effect through the mediating variable (earnings quality attributes, EQ) can be calculated by the product

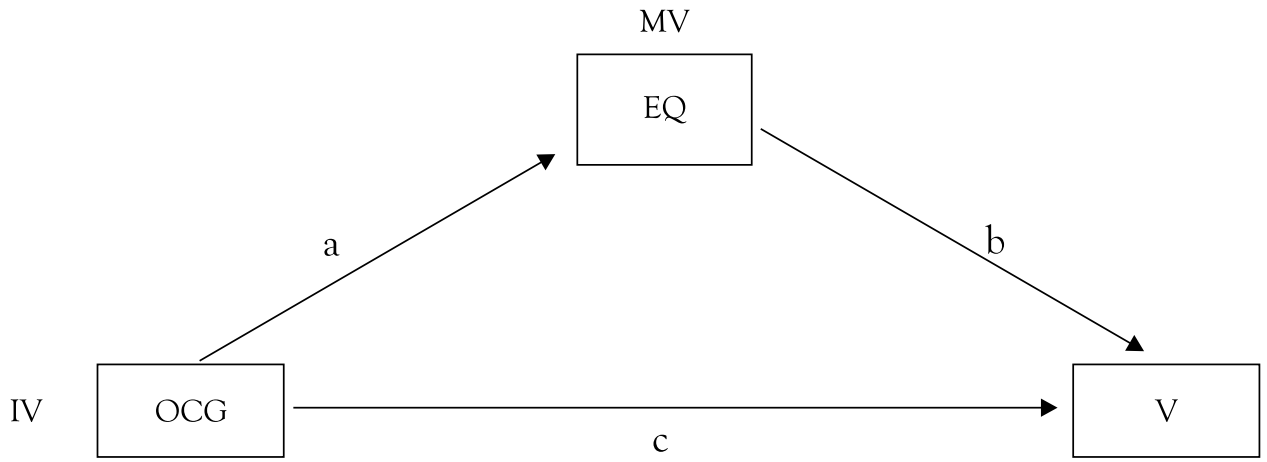

Figure 1: Causal Association Among Overall Corporate Governance, Earnings Quality Attributes and Value of the Firm

of "a" and "b" paths as "ab". According to Hayes and Preacher (2014), all paths can be quantified by using the regressions.

\subsection{Empirical model and estimation methods}

In order to capture the direct as well as indirect effects of overall corporate governance (OCG) on value of firm $(\mathrm{V})$ as shown in Figure 1, we construct our econometric model as follows: 


$$
\begin{gathered}
E Q_{i, t}=\alpha_{0}+\alpha_{1} O C G_{i t}+\alpha_{2} F S_{i t}+\alpha_{3} L V G_{i t}+\alpha_{4} C A I_{i t}+\alpha_{5} G W_{i t}+\varepsilon_{1 i t} \\
V_{i, t}=\beta_{0}+\beta_{1} O C G_{i t}+\beta_{2} E Q_{i t}+\beta_{3} F S_{i t}+\beta_{4} L V G_{i t}+\beta_{5} C A I_{i t}+\beta_{6} G W_{i t}+\varepsilon_{2 i t}
\end{gathered}
$$

where, EQ is earnings quality attributes, OCG is overall corporate governance, FS is firm size, LVG is leverage, CAI is capital intensity, GW is growth opportunities, $\mathrm{V}$ is value of firm, $\varepsilon_{1}$ it and $\varepsilon_{2}$ it are stochastic error terms. Equation (7) represents the effect of OCG on mediating variable (EQ) using the control variables such as FS, LVG, CAI and GW. Equation (8) captures the effects of OCG and EQ on value of firm (V). Using equations (7) and (8), we calculate the direct and indirect effects of OCG on $\mathrm{V}$ as follows

\subsection{Direct effect}

$$
\frac{\partial V}{\partial O C G}=\beta_{1} \text {, using equation (7) }
$$

\subsection{Indirect effect through the channel of EQ}

$$
\theta=\frac{\partial V}{\partial O C G}=\frac{\partial E Q}{\partial O C G} * \frac{\partial V}{\partial E Q}=\alpha_{1} * \beta_{2} \text {, using equations (6) and (7) }
$$

\subsection{Estimation method}

The most frequently used procedures for panel data analysis are the one-way random effect (RE) and fixed effect (FE) models. These models assume that the differences among cross-sectional units (firms) can be captured by an intercept term, which is specific for each firm. This specific intercept term is considered as random in RE models and fixed in the FE models. However, the econometric methods available for the estimation of a system of equations for unbalanced panel-data are relatively new. Biørn (2004) develops a procedure for the estimation of a one-way Seemingly Unrelated Regression (SUR) system with random effects (RE). Monte Carlo simulations show that SUR techniques are superior as compared to the standard single equation FE and RE estimators. Therefore, we estimate equations (6) and (7) simultaneously using SUR with one-way random effects (RE) as suggested by Biørn (2004). We prefer RE to FE with selection determined by Hausman (1978). This procedure has several advantages. For example, it is possible to control firm-level heterogeneity in order to avoid biased estimates. Furthermore, due to time and cross-firm dimensions, there is more information, less collinearity and greater efficiency in the estimates (Biørn, 2004; Baltagi, 2005).

\section{Analysis and Results}

\subsection{Measurement of overall corporate governance (OCG)}

As discussed in the methodology section, Principal Component Analysis is used 
to measure the overall corporate governance following Larcker et al. (2007). For this purpose, ten internal and external corporate governance mechanisms are taken into account as input variables (Appendix-1). PCA determines the principal components after the decomposition of Eigen value of the correlation matrix. It only considers those input factors which highly play an important role in the variation of the whole input data. If correlation matrix is accurate then it guarantees the validity of principal components and the final conclusions are considered valid. PCA mitigates the individual identity of highly correlated variables and produces minimum output variables. So it is our aim of using PCA to condense the initial input components without losing information.

\subsection{Corporate governance (independent variable) and earnings quality attributes (mediator)}

Table 2: Regression Results of Model 6

\begin{tabular}{|c|c|c|c|c|c|}
\hline Variable & PRS & PRED & VR & $\mathrm{AQU}$ & SM \\
\hline OCG & $0.0097(0.240)$ & $\begin{array}{c}0.0034^{* * *} \\
(0.000)\end{array}$ & $\begin{array}{c}0.0277^{* * *} \\
(0.000)\end{array}$ & $\begin{array}{c}-0.0067^{* * *} \\
(0.000)\end{array}$ & $\begin{array}{c}-0.0220^{* * *} \\
(0.008)\end{array}$ \\
\hline FS & $\begin{array}{c}0.0167^{* * *} \\
(0.003)\end{array}$ & $\begin{array}{l}0.0004 \\
(0.336)\end{array}$ & $\begin{array}{c}0.0165^{* * *} \\
(0.000)\end{array}$ & $\begin{array}{c}0.0073^{* * *} \\
(0.000)\end{array}$ & $\begin{array}{c}0.0194^{* * *} \\
(0.001)\end{array}$ \\
\hline LVG & $\begin{array}{c}1.206^{* * *} \\
(0.000)\end{array}$ & $\begin{array}{r}-0.0015 \\
(0.777) \\
\end{array}$ & $\begin{array}{c}-0.1770^{* * *} \\
(0.000)\end{array}$ & $\begin{array}{c}-0.1052^{* * *} \\
(0.000)\end{array}$ & $\begin{array}{c}1.1676^{* * *} \\
(0.000)\end{array}$ \\
\hline CAI & $\begin{array}{c}-0.9386^{* * *} \\
(0.000)\end{array}$ & $\begin{array}{c}0.0311^{* * *} \\
(0.000)\end{array}$ & $\begin{array}{c}0.0814^{* * *} \\
(0.000)\end{array}$ & $\begin{array}{c}-0.0270^{* * *} \\
(0.000)\end{array}$ & $\begin{array}{c}-1.5488^{* * *} \\
(0.000)\end{array}$ \\
\hline GW & $\begin{array}{c}-0.0175^{* * *} \\
(0.001)\end{array}$ & $\begin{array}{c}-0.0011^{* * *} \\
(0.000)\end{array}$ & $\begin{array}{c}-0.0046^{* * *} \\
(0.000)\end{array}$ & $0.0001(0.897)$ & $\begin{array}{c}0.0091^{*} \\
(0.069)\end{array}$ \\
\hline
\end{tabular}

Note: P-values are given in parentheses. ${ }^{* * *}$, ${ }^{* *}$ and ${ }^{*}$ show the level of significance at $1 \%, 5 \%$ and $10 \%$ respectively.

Table 2 reports the results of model 6 , which investigates the relationship among corporate governance and five earnings quality attributes along with control variables.

In columns 2 to 6 of Table 2, results of the model- 6 (where PRS, PRED, VR, AQ and $\mathrm{SM}$ are dependent variables and OGC is an independent variable along with other control variables) are presented. Accrual quality (AQU) and smoothness (SM) are the inverse measures of earnings quality, as explained in the methodology section. The results show that corporate governance is affecting the reliability and relevancy attributes of financial reporting quality significantly and positively, as indicated by p-value which is less than $1 \%$ level. It means that an increase in the level of corporate governance would result in a higher level of earnings quality attributes. These 
results prove the stakeholder's theory and the role of corporate governance. Another explanation of the findings can be elaborated as: the better corporate governance improves the earnings quality, by reducing the agency problem arising due to asymmetric information among managers and shareholders, so the better governance decreases the probability of information asymmetry and strength of corporate governance serves as a tool to monitor the financial reporting process. Therefore, it is argued that improvement in corporate governance mechanisms would result in greater quality of financial reporting. These findings are consistent with those of Aldamen and Duncan (2016); Mollah, Farooque, Asma, and Molyneux (2015).

Moreover, firm size is positively associated with earnings quality attributes, as larger firms are under political visibility and regulations. Therefore, managers have less discretionary powers to manage the earnings. Leverage negatively affects the earnings quality, may be, due to debt covenants, managers are involved in management of the earnings. However, leverage has a positive impact on persistance and smoothness, which indicates that debt covenants compell managers to minimize the earnings volatility as measured through persistance and smoothness (Ahmed Sheikh, Wang, \& Khan 2013). Capital intensity has a negative impact on the level of earnings quality as such firms have higher level of accruals. Francis et al. (2004) find the same results regarding capital intensity. Capital intensive firms have more predictable and value relevant earnings figure. Growth is negatively associated with earnings quality, as for low growth firms managers have to face pressure to meet the numbers. As a result the level of accruals are increased.

\subsection{Combined effect of corporate governance and earnings quality attributes on value of the firm}

Table 3 reports the results of model 7. This model demonstrates the combined effects of corporate governance and earnings quality attributes on value of the firm. Our estimation results indicate that the overall corporate governance has a significant and negative impact on ROA-accounting based measures of value of the firm after controlling the effects of earnings quality attributes. A plausible reason for this distinct and contrasting coefficient can be explained as follows: In Pakistan, family owned entities are common and the earnings figure is presented in accordance with the requirements of owners. Irregularities in the accounting figure increase the information risk which reduces the value of the firm. As far as accrual quality and smoothness (inverse measures of earnings quality) are concerned, the results indicate that earnings manipulations are controlled by effective corporate governance mechanism. Consequently the value of firm is improved.

Corporate governance affects the Tobin-Q positively and significantly at a $1 \%$ level. 
These findings explain that better corporate governance helps to reduce the agency problem arising due to asymmetric information among managers and shareholders. Therefore, better governance decreases the probability of information asymmetry and strength of corporate governance serves as tool to monitor the managers. These results are aligned with the stewardship theory which suggests that managers strive for the organizational objectives rather than their own objectives. The results show that the firms are performing better due to the implementation of the corporate governance code in Pakistan. Ammann et al. (2011) state two reasons those may boost the value of firm. Firstly, better governance mechanism leads to higher prices of stocks as investors know that they would get higher cash flows in their dividends and increased shareholders' wealth. Secondly, good governance specifies that the monitoring costs on the part of shareholders as well as cost of audit are lower. Consequently, cost of capital of well governed firms will be lower accompanied by higher value. These findings are consistent with Ben (2014), Javaid and Saboor (2015), and Narwal and Jindal (2015).

The results depict that persistence, predictability, value relevance, accrual quality and smoothness improve the value of firm significantly as measured by ROA at a $1 \%$ level after controlling the effect of corporate governance and other control variables. Furthermore, all earnings quality attributes have a significant positive affect on Tobin-Q, a market based measure. However, persistence and smoothness negatively affect the Tobin-Q at a $1 \%$ level. Persistence and smoothness are considered desirable attributes of the earnings, derived from the notion that managers disseminate the less volatile earnings figure, which is a good indicator of future earnings (Francis et al., 2004). However, according to contrasting view, both are the indicators of managerial opportunistic behavior towards the alteration of accounting standards (Leuz et al., 2003). Additionally, it is found that less variability in earnings is pronounced more to the market measure of value of the firm. The results of this model demonstrate that the improvement in earnings quality results in both decrease in the information asymmetry and wrong reporting to stakeholders. Due to reduction in information risk, the stakeholders feel confidence in purchasing the stocks of such companies which drive up the market value of the firms. These results are aligned with the efficient contracting hypothesis of positive accounting theory (Watts \& Zimmerman, 1986).

Table 3: Regression Results of Model 7

\begin{tabular}{|c|c|c|}
\hline & ROA & Tobin-Q \\
\hline Panel-1 & & \\
\hline PRS & $0.0561(0.000)^{* * *}$ & $-0.4548(0.000)^{* * *}$ \\
\hline OCG & $-0.0026(0.000)^{* * *}$ & $0.0369(0.000)^{* * *}$ \\
\hline FS & $0.0078(0.000)^{* * *}$ & $0.0287(0.000)^{* * *}$ \\
\hline
\end{tabular}




\begin{tabular}{|c|c|c|}
\hline LVG & $-0.1486(0.000)^{* * *}$ & $0.7492(0.000)^{* * *}$ \\
\hline CAI & $-0.0452(0.000)^{* * *}$ & $-0.4031(0.000)^{* * *}$ \\
\hline GW & $0.0133(0.000)^{* * *}$ & $0.1574(0.000)^{* * *}$ \\
\hline \multicolumn{3}{|l|}{ Panel-1I } \\
\hline PRED & $0.2009(0.000)^{* * *}$ & $0.0352(0.011)^{* * *}$ \\
\hline OCG & $-0.0012(0.000)^{* * *}$ & $0.0064(0.000)^{* * *}$ \\
\hline FS & $0.0086(0.000)^{* * *}$ & $0.0065(0.000)^{* * *}$ \\
\hline LVG & $-0.0952(0.000)^{* * *}$ & $0.7637(0.000)^{* * *}$ \\
\hline CAI & $-0.1020(0.000)^{* * *}$ & $-0.4350(0.000)^{* * *}$ \\
\hline GW & $0.0121(0.000)^{* * *}$ & $0.1195(0.000)^{* * *}$ \\
\hline \multicolumn{3}{|l|}{ Panel-1II } \\
\hline VR & $0.6013(0.000)^{* * *}$ & $0.2111(0.055)^{* *}$ \\
\hline OCG & $-0.0160(0.000)^{* * *}$ & $0.0358(0.000)^{* * *}$ \\
\hline FS & $-0.0013 \quad(0.212)$ & $0.0185(0.000)^{* * *}$ \\
\hline LVG & $0.0049 \quad(0.675)$ & $0.5749(0.000)^{* * *}$ \\
\hline CAI & $-0.1409(0.000)^{* * *}$ & $-0.2134(0.000)^{* * *}$ \\
\hline GW & $0.0170(0.000)^{* * *}$ & $0.1288(0.000)^{* * *}$ \\
\hline \multicolumn{3}{|l|}{ Panel-1V } \\
\hline AQU & $-0.0067(0.000)^{* * *}$ & $-0.0462(0.000)^{* * *}$ \\
\hline OCG & $-0.0043(0.000)^{* * *}$ & $0.0365(0.002)^{* * *}$ \\
\hline FS & $0.0136(0.000)^{* * *}$ & $0.0315(0.000)^{* * *}$ \\
\hline LVG & $-0.1486(0.000)^{* * *}$ & $-0.2710(0.000)^{* * *}$ \\
\hline CAI & $-0.0978(0.000)^{* * *}$ & $0.1187(0.000)^{* * *}$ \\
\hline GW & $0.0136(0.000)^{* * *}$ & $0.1334(0.000)^{* * *}$ \\
\hline \multicolumn{3}{|l|}{ Panel-V } \\
\hline SM & $-0.8037(0.000)^{* * *}$ & $0.6894(0.000)^{* * *}$ \\
\hline OCG & $-0.0208(0.002)^{* * *}$ & $0.0426(0.000)^{* * *}$ \\
\hline FS & $0.0276(0.000)^{* * *}$ & $0.0184(0.000)^{* * *}$ \\
\hline LVG & $0.8427(0.000)^{* * *}$ & $0.5171(0.000)^{* * *}$ \\
\hline CAI & $-1.3243(0.000)^{* * *}$ & $0.8176(0.000)^{* * *}$ \\
\hline GW & $0.0202(0.000)^{* * *}$ & $0.1471(0.000)^{* * *}$ \\
\hline
\end{tabular}


The possible explanation is that the financial accounting information, having better quality, enhances the coordination between investor and firm in the form of capital investments, reduction in information risk and ultimately reduction in cost of the capital. Furthermore, these findings suggest that reliability and relevancy of financial reporting are the key elements for stakeholders in their decision making process. These findings are consistent with Gaio and Raposo (2014); Goettsche, Steindl, and Gietl (2014). Financial reporting of higher quality helps to reduce litigations against the firms and improves the investment efficiency, and avoids the over-investment (Lara, Osma, and Penalva, 2016). These findings suggest that predictive power of earnings significantly contributes in the value of firm determination (Peterson, Schmardebeck, \& Wilks, 2015).

Firm size positively affects the value of the firm, as large firms can attain the economies of scale and possess the range of capabilities. These features positively influence the value of the firm (Ehikioya, 2009). Leverage (LVG) is negatively associated with ROA and Tobin-Q as debt obligations compell the firm to forego the projects with positive NPV. However, leverage has a positive impact on the value of firm and indicates that debt covenants discourage the opportunistic behaviors of managers towards free cash flows (Ahmed et al., 2013). Further, lenders of the firm positively affect the accounting earnings by actively monitoring the managemnt (Choi, Park, $\&$ Yoo, 2007). Capital intensity has a negative effect on value of firms as higher level of accruals creates information aysmmetry among managers and shareholders, which decrease the value of the firm. Additionally, growth has a positive impact on value of firm at a $1 \%$ level of significance as growth firms have access to more resources.

\subsection{Indirect effect of earnings quality attributes in governance-value association}

In this section, the results regarding the causal association between overall corporate governance, earnings quality attributes and value of firm are presented. To capture the indirect effect of overall corporate governance on value of firm through earnings quality attributes, the process involves two functions named (1) EQ (mediating variable)-Function as modeled 6, and, (2) Value (dependent variable)-Function as modeled 7 in methodology section. The product of EQ-Function and Value-function is termed as " $\theta$ " (see section 3.7).

Table 4 reports estimation for the hypothesis 2 to determine whether overall corporate governance affects the value of firm through earnings quality attributes. Panel-I, reflects that overall corporate governance insignificantly affects value of firm (for both measures) through its effects on persistence (mediator). These results imply that the overall corporate governance has no discernible effect on value through persistence. 
The results for the proposition, that corporate governance affects the value of firm through predictive power of earnings, are presented in Panel-II. These findings show that the overall corporate governance has a positive and significant effect on value through predictability of earnings. It is evident from the results that as the level of corporate governance increases, value also increases through the inclusion of another variable as the mediator, that is, predictability. The predictability of earnings is the ability of historical earnings to forecast the future earnings. The findings show that corporate governance positively affects the predictive power of earnings and by developing the anticipation of future earnings, the stakeholders can forecast about the future cash flows and earnings that support their decision making.

Panel-III presents the results for the proposition, whether value relevance mediates in the association of corporate governance and value of firm or not. The results are consistent to the previous investigation which shows that corporate governance positively affects the value of the firm through its impact on the value relevance. Value relevance shows the reliability of financial reporting. Good corporate governance ensures the reliability of financial reporting, which in turn reduces the asymmetric level of accounting information. The output of the reduced information asymmetry leads to improvement in the value of the firm in all measures.

Table 4: Indirect Effects-Model 8

\begin{tabular}{|c|c|c|}
\hline Channel of Earnings Quality & Value of firm & Indirect effects \\
\hline \multirow[t]{2}{*}{ Panel -I Persistence (PRS) } & $\mathrm{ROA}$ & $0.0005(0.240)$ \\
\hline & Tobin-Q & $0.0016(0.608)$ \\
\hline \multirow{2}{*}{$\begin{array}{c}\text { Panel -II Predictability } \\
\text { (PRED) }\end{array}$} & $\mathrm{ROA}$ & $0.0007^{* * *}(0.000)$ \\
\hline & Tobin-Q & $-0.0004^{* *}(0.023)$ \\
\hline \multirow{2}{*}{$\begin{array}{c}\text { Panel -III Value Relevance } \\
\text { (VR) }\end{array}$} & $\mathrm{ROA}$ & $0.0167^{* * *}(0.000)$ \\
\hline & Tobin-Q & $0.0003 *(0.064)$ \\
\hline \multirow{2}{*}{$\begin{array}{l}\text { Panel -IV Accrual Quality } \\
\text { (AQU) }\end{array}$} & $\mathrm{ROA}$ & $0.0047^{* * *}(0.000)$ \\
\hline & Tobin-Q & $0.0002(0.181)$ \\
\hline \multirow[t]{2}{*}{ Panel -V Smoothness (SM) } & $\mathrm{ROA}$ & $0.0176^{* * *} \quad(0.008)$ \\
\hline & Tobin-Q & $-0.0144^{* * *}(0.002)$ \\
\hline
\end{tabular}

Note: P-values are given in parentheses. ${ }^{* * *},{ }^{* *}$ and ${ }^{*}$ show the level of significance at $1 \%, 5 \%$ and $10 \%$ respectively.

Accrual quality role in the governance and value relationship has been presented in Panel-IV of the Table. Significantly, the results indicate the key role of accrual quality as a mediator in the association between corporate governance and value of firm. The findings show that better corporate governance leads to a significant increase in 
the value of the firm through its impact on quality of accruals.

Finally, in Panel-V, the proposition that smoothness mediates the governance and value association is examined. The results depict that corporate governance has a significant positive effect on all measures of value of firm through its impact on smoothness. These findings support the idea that managers smoothen out the transitory and irrelevant fluctuations in cash flows to reveal their private information regarding firm performance (Francis et al., 2004). This positive aspect provides reliable information to the stakeholders of the firm. Dechow et al. (2010) argue that opportunistic smoothening of earnings is common in various countries. Consequently, asymmetric level of information is reduced and value of firm is improved.

In short, corporate governance has a significant positive effect on value of firm in terms of monitoring and strategic role, through its impact on reliability and relevancy of financial reporting.

\section{Conclusion}

Earlier literature on overall corporate governance and value of firm depicts the inconclusive results regarding their relationship. Furthermore, the existing literature is silent on the indirect effects of financial reporting quality in this association, thus providing only a only a partial view (Habib \& Jiang, 2015). Keeping this argument in view, this study examines the governance-value relationship from a new dimension, that is, the role of financial reporting quality as a mediating variable in the governance-value relationship. This is, after all, the main objective of the study. For estimation purpose, we use seemingly unrelated regression method with random effects in the context of panel data as suggested by Biørn (2004).

In order to obtain a composite measure of overall corporate governance, we use Principal Component Analysis considering eleven dimensions. Five earnings quality attributes are taken to measure the reliability and relevancy of reporting quality, that is, persistence, predictability, value relevance, accrual quality and smoothness. Our results show that the overall corporate governance increases the level of reliability and relevancy of financial reporting. It can be viewed that higher earnings quality lowers the information asymmetry and systematic risk which reduces the cost of capital and increases the value of the firm. Further, the overall corporate governance has positive and significant impact (direct) on value of firm. The indirect effects of overall corporate governance on value of firm through the channel of various attributes of earnings quality (such as predictability, value relevance, accrual quality and smoothness) are also positive and significant which confirms partial mediation in governance-value relationship. These results support the view that effective corporate governance en- 
hances the financial reporting quality, reduces information asymmetries and hence increases the value of firm. These findings are helpful for practitioners, policy makers and regulators of the developing economies like Pakistan. However, the results may be subject to intrinsic biases involved in the model's estimation.

\section{References}

Ahmed Sheikh, N., Wang, Z., \& Khan, S. (2013). The impact of internal attributes of corporate governance on firm performance: evidence from Pakistan. International Journal of Commerce and Management, 23(1), 38-55.

Akbar, S., Poletti-Hughes, J., El-Faitouri, R., \& Shah, S. Z. A. (2016). More on the relationship between corporate governance and firm performance in the UK: Evidence from the application of generalized method of moments estimation. Research in International Business and Finance, 38, 417-429.

Akileng, G. (2014). The efficacy of corporate governance in reducing opportunistic accounting earnings manipulations. Management, 5(24), 44-69.

Al-Malkawi, H.-A. N., Pillai, R., \& Bhatti, M. (2014). Corporate governance practices in emerging markets: The case of GCC countries. Economic Modelling, 38, 133-141.

Aldamen, H., Duncan, K., \& Martinov-Bennie, N. (2016). Does good corporate governance enhance accruals quality during financial crises? Managerial Auditing Journal, 31(4/5).

Shah, S. Z. A., \& Butt, S. A. (2009). The impact of corporate governance on the cost of equity: Empirical evidence from Pakistani listed companies. The Lahore Journal of Economics, 14(1), 139-171.

Ammann, M., Oesch, D., \& Schmid, M. M. (2011). Corporate governance and firm value: International evidence. Journal of Empirical Finance, 18(1), 36-55.

Baltagi, B. (2005). Econometric analysis of panel data (3 $3^{\text {rd }}$ ed.). England: John Wiley \& Sons.

Ben, P. J. (2014). Corporate governance index and firm performance. Journal of Contemporary Research in Management, 9(3), 33-44.

Bhandari, V., Lamba, A., \& Seth, R. (2013). Does corporate governance increases firm performance and value among specific sectors in indian context? An empirical analysis. Available at SSRN: https://papers.ssrn. com/sol3/papers.cfm?abstract_id=2601243.

Biørn, E. (2004). Regression systems for unbalanced panel data: A stepwise maximum likelihood procedure. Journal of Econometrics, 122(2), 281-291.

Board, F. A. S. (2010). Conceptual framework for financial reporting. Statement of financial accounting concepts No. 8: FASB Norwalk, CT.

Bowen, R. M., Rajgopal, S., \& Venkatachalam, M. (2008). Accounting discretion, corporate governance, and firm performance. Contemporary Accounting Research, 25(2), 351-405. 
Braam, G., \& Beest, F. v. (2013). A conceptually-based empirical analysis on quality differences between UK annual reports and US 10-K reports. Journal of Modern Accounting and Auditing, 9(10), 1281-1301.

Bushman, R. M., \& Smith, A. J. (2001). Financial accounting information and corporate governance. Journal of Accounting and Economics, 32(1), 237-333.

Choi, J. J., Park, S. W., \& Yoo, S. S. (2007). The value of outside directors: Evidence from corporate governance reform in Korea. Journal of Financial and Quantitative Analysis, 42(04), 941-962.

Claessens, S., \& Yurtoglu, B. B. (2013). Corporate governance in emerging markets: A survey. Emerging Markets Review, 15, 1-33.

Dechow, P., Ge, W., \& Schrand, C. (2010). Understanding earnings quality: A review of the proxies, their determinants and their consequences. Journal of Accounting and Economics, 50(2), 344-401.

DeFond, M. L. (2010). Earnings quality research: Advances, challenges and future research. Journal of Accounting and Economics, 50(2), 402-409.

Dimitropoulos, P. E., \& Asteriou, D. (2010). The effect of board composition on the informativeness and quality of annual earnings: Empirical evidence from Greece. Research in International Business and Finance, 24(2), 190-205.

Ehikioya, B. I. (2009). Corporate governance structure and firm performance in developing economies: evidence from Nigeria. Corporate Governance: The International Journal of Business in Society, 9(3), 231-243.

Firth, M., Fung, P. M., \& Rui, O. M. (2007). Ownership, two-tier board structure, and the informativeness of earnings-Evidence from China. Journal of Accounting and Public Policy, 26(4), 463-496.

Francis, J., LaFond, R., Olsson, P. M., \& Schipper, K. (2004). Costs of equity and earnings attributes. The Accounting Review, 79(4), 967-1010.

Frost, C., Gordon, E., \& Pownall, G. (2005). Financial reporting quality, disclosure, and emerging market companies' access to capital in global equity markets. School of Accountancy.

Gaio, C., \& Raposo, C. C. (2014). Corporate governance and earnings quality: International evidence. Journal of Accounting and Finance, 14(3), 52.

Goettsche, M., Steindl, T., \& Gietl, S. (2014). Do customers affect the value relevance of sustainability reporting? Empirical evidence on stakeholder interdependence. Business Strategy and the Environment, 25(3), 149-164

Gompers, P., Ishii, J., \& Metrick, A. (2003). Corporate governance and equity prices. The Quarterly Journal of Economics, 118(1), 107-156.

Gray, G. L., Turner, J. L., Coram, P. J., \& Mock, T. J. (2011). Perceptions and misperceptions regarding the unqualified auditor's report by financial statement preparers, users, and auditors. Accounting Horizons, 25(4), 659-684. 
Habib, A., \& Jiang, H. (2015). Corporate governance and financial reporting quality in China: A survey of recent evidence. Journal of International Accounting, Auditing and Taxation, 24, 29-45.

Hausman, J. A. (1978). Specification tests in econometrics. Econometrica: Journal of the Econometric Society, 46(6),1251-1271.

Hayes, A. F., \& Preacher, K. J. (2014). Statistical mediation analysis with a multicategorical independent variable. British Journal of Mathematical and Statistical Psychology, 67(3), 451-470.

Ismail, T. H., \& Elbolok, R. (2011). Do conditional and unconditional conservatism impact earnings quality and stock prices in Egypt? Research Journal of Finance and Accounting, 2(12), 7-22.

Javaid, F., \& Saboor, A. (2015). Impact of corporate governance index on firm performance: Evidence from Pakistani manufacturing sector. Journal of Public Administration and Governance, 5(2), 1-21.

Javed, A. Y., Iqbal, R., \& Hasan, L. (2006). Corporate governance and firm performance: Evidence from Karachi Stock Exchange. The Pakistan Development Review, 45(4), 947-964.

Jensen, M. C., \& Meckling, W. H. (1979). Theory of the firm: Managerial behavior, agency costs, and ownership structure. In K. Brunner (Ed.), Economics and social institutions. (pp. 163-231). Springer, Dordrecht.

Jiang, W., Lee, P., \& Anandarajan, A. (2008). The association between corporate governance and earnings quality: Further evidence using the GOV-Score. Advances in Accounting, 24(2), 191-201.

Kang, S.-A., \& Kim, Y.-S. (2011). Does earnings management amplify the association between corporate governance and firm performance?: Evidence from Korea. International Business $\mathfrak{E}$ Economics Research Journal (IBER), 10(2), 53-66.

Kim, K. S., Lee, J. H., \& Chung, C. Y. (2015). Accrual quality and opportunistic seasoned equity offering in the Korean Stock Market. Emerging Markets Finance and Trade, 51(sup3), 140-157.

Klapper, L. F., \& Love, I. (2004). Corporate governance, investor protection, and performance in emerging markets. Journal of Corporate Finance, 10(5), 703-728.

Krishnan, G. V., \& Parsons, L. M. (2008). Getting to the bottom line: An exploration of gender and earnings quality. Journal of Business Ethics, 78(1-2), 65-76.

Lambright, K. T. (2009). Agency theory and beyond: Contracted providers' motivations to properly use service monitoring tools. Journal of Public Administration Research and Theory, 19(2), 207-227.

Lara, J. M. G., Osma, B. G., \& Penalva, F. (2016). Accounting conservatism and firm investment efficiency. Journal of Accounting and Economics, 61(1), 221-238.

Larcker, D. F., Richardson, S. A., \& Tuna, I. (2007). Corporate governance, accounting outcomes, and organizational performance. The Accounting Review, 82(4), 963-1008.

Leuz, C., Nanda, D., \& Wysocki, P. D. (2003). Earnings management and investor protection: An 
international comparison. Journal of Financial economics, 69(3), 505-527.

Lyimo, G. D. (2014). Assessing the measures of quality of earnings: Evidence from India. European Journal of Accounting Auditing and Finance Research, 2(6), 17-28.

Madhani, P. M. (2014). Study of relationship between capital intensity and corporate governance practices of firms listed in Indian Stock Exchange: A sectoral analysis. The Great Lakes Herald, 8(1), 1-21.

Mahoney, L., \& Roberts, R. W. (2007). Corporate social performance, financial performance and institutional ownership in Canadian firms. Paper presented at the Accounting Forum (Vol. 31, No. 3, pp. 233 253). Elsevier.

Mollah, S., Farooque, O. A., Asma, M., \& Molyneux, P. (2015). Bank corporate governance and future earnings predictability. Available at SSRN: https://ssrn.com/abstract=2607098.

Narwal, K., \& Jindal, S. (2015). The Impact of corporate governance on the profitability: An empirical study of indian textile industry. International Journal of Research in Management, Science $\mathcal{E}$ Technology, $3(2), 81-85$.

Nita, B. (2007). Transformation of management accounting: from management control to performance management. Transformations in Business $\mathcal{E}$ Economics, 7(3), 15.

Ohlson, J. A. (1995). Earnings, book values, and dividends in equity valuation. Contemporary Accounting Research, 11(2), 661-687.

Palea, V. (2013). IAS/IFRS and financial reporting quality: Lessons from the European experience. China Journal of Accounting Research, 6(4), 247-263.

Penman, S. H., \& Zhang, X.J. (2002). Accounting conservatism, the quality of earnings, and stock returns. The Accounting Review, 77(2), 237-264.

Perotti, P., \& Wagenhofer, A. (2014). Earnings quality measures and excess returns. Journal of Business Finance $\mathcal{B}$ Accounting, 41(5-6), 545-571.

Peterson, K., Schmardebeck, R., \& Wilks, T. J. (2015). The earnings quality and information processing effects of accounting consistency. The accounting review, 90(6), 2483-2514.

Pincus, M., Rajgopal, S., \& Venkatachalam, M. (2007). The accrual anomaly: International evidence. The Accounting Review, 82(1), 169-203.

Pucheta Martínez, M. C., \& García Meca, E. (2014). Institutional investors on boards and audit committees and their effects on financial reporting quality. Corporate Governance: An International Review, 22(4), 347-363.

Rodriguez-Ariza, L., Martínez-Ferrero, J., \& Bermejo-Sánchez, M. (2016). Consequences of earnings management for corporate reputation: Evidence from family firms. Accounting Research Journal, 29(4), 457-474. 
Salerno, D. (2013). The role of earnings quality in financial analyst forecast accuracy. Journal of Applied Business Research (JABR), 30(1), 255-276.

Shahwan, T. M. (2015). The effects of corporate governance on financial performance and financial distress: Evidence from Egypt. Corporate Governance, 15(5), 641-662.

Shan, Y. G. (2015). Value relevance, earnings management, and corporate governance in China. Emerging Markets Review, 23, 186-207.

Skinner, D. J., \& Srinivasan, S. (2012). Audit quality and auditor reputation: Evidence from Japan. The Accounting Review, 87(5), 1737-1765.

Tasios, S., \& Bekiaris, M. (2012). Auditor's perceptions of financial reporting quality: the case of Greece. International Journal of Accounting and Financial Reporting, 2(1), 57-74.

Varshney, P., Kaul, V. K., \& Vasal, V. (2013). Corporate governance mechanisms and firm performance: a study of select Indian firms. Afro-Asian Journal of Finance and Accounting, 3(4), 341-395.

Watts, R. L., \& Zimmerman, J. L. (1986). Positive accounting theory. Englewood Cliffs, N.J.: Prentice-Hall.

Weir, C., Laing, D., \& McKnight, P. J. (2002). Internal and external governance mechanisms: Their impact on the performance of large UK public companies. Journal of Business Finance $\mathcal{E}$ Accounting, 29(56), 579-611. 


\section{Appendix-1 Principal component matrix}

\begin{tabular}{|c|c|c|c|}
\hline CG Attributes & $\begin{array}{l}\text { Acro- } \\
\text { nyms }\end{array}$ & Operationalization/Measurements & $\begin{array}{c}\text { Principal } \\
\text { components }\end{array}$ \\
\hline Size & FS & Natural log of total assets & 0.3762 \\
\hline CEO Duality & DUL & $\begin{array}{c}\text { Dummy variable taking the value } 1 \text { if the firm's } \\
\text { CEO is the chairman of the board of directors, } \\
\text { otherwise } 0 .\end{array}$ & -0.2266 \\
\hline $\begin{array}{l}\text { Managerial/Direc- } \\
\text { tor Ownership }\end{array}$ & $\mathrm{BSH}$ & $\begin{array}{l}\text { Calculated as the total percentage of shares owned } \\
\text { by board of directors for firm i in time t. }\end{array}$ & -0.4412 \\
\hline $\begin{array}{l}\text { Institutional } \\
\text { ownership }\end{array}$ & ILO & $\begin{array}{l}\text { Shares held by Institutional owners divided by total } \\
\text { number of shares outstanding }\end{array}$ & 0.1980 \\
\hline $\begin{array}{l}\text { Ownership Con- } \\
\text { centration }\end{array}$ & LSH & $\begin{array}{l}\text { Calculated as Percentage of total shares held by the } \\
\text { top } 05 \text { shareholders divided by the total number of } \\
\text { shares for firm i in time t. }\end{array}$ & 0.1601 \\
\hline Board Size & BS & $\begin{array}{l}\text { Calculated as the number of board directors for } \\
\text { firm i in time t. }\end{array}$ & 0.3964 \\
\hline Board Meetings & $\mathrm{BM}$ & $\begin{array}{l}\text { Calculated as the number of board directors meet- } \\
\text { ing during the financial year. }\end{array}$ & 0.0547 \\
\hline $\begin{array}{l}\text { Board Indepen- } \\
\text { dence }\end{array}$ & BIN & $\begin{array}{l}\text { Calculated as the proportion of outside indepen- } \\
\text { dent directors for firm i in time t. }\end{array}$ & 0.2962 \\
\hline $\begin{array}{l}\text { Audit Committee } \\
\text { Independence }\end{array}$ & AIN & $\begin{array}{l}\text { Calculated as the proportion of independent direc- } \\
\text { tors on the audit committee for firm i in time t. }\end{array}$ & 0.3773 \\
\hline $\begin{array}{l}\text { Audit Committee } \\
\text { Meetings }\end{array}$ & AM & $\begin{array}{l}\text { Calculated as the number of audit committee meet- } \\
\text { ings during the financial year for firm } \mathrm{i} \text { in time } \mathrm{t} \text {. }\end{array}$ & 0.1141 \\
\hline Audit quality & AQ & $\begin{array}{l}\text { To control for the effect of external auditor quality, } \\
\text { a dummy variable for auditor quality (BIG4), } \\
\text { taking the value } 1 \text { if the firm was audited by a Big } 4 \\
\text { auditor otherwise } 0 \text {. }\end{array}$ & 0.3800 \\
\hline
\end{tabular}

$\mathrm{OCG}=0.3762^{*} \mathrm{FS}+(-0.2266)^{*} \mathrm{DUL}+(-0.44120)^{*} \mathrm{BSH}+$ $+0.38^{*} \mathrm{AQ}$

The above calculated index does not guarantee the reflection of intrinsic competence of the corporate governance but rather an optimized measure. 
